\title{
Folliculinid ciliates: a new threat to Caribbean corals?
}

\author{
Aldo Cróquer ${ }^{1, *}$, Carolina Bastidas ${ }^{1}$, Diana Lipscomb ${ }^{2}$ \\ ${ }^{1}$ Departamento de Biología de Organismos, Universidad Simón Bolívar, Caracas 1080-A, Venezuela \\ ${ }^{2}$ Department of Biological Sciences, George Washington University, Washington, DC 20052, USA
}

\begin{abstract}
This is the first report of a putative pathogenic ciliate protozoan that has been associated with Caribbean corals. Previously, only 2 species of the phylum Ciliophora had been linked to coral diseases, and they were exclusive to the Indo-Pacific region. In this study, a ciliate of the genus Halofolliculina was found on 10 hard coral species at the National Parks of Los Roques and Morrocoy, Venezuela. The general morphology of this ciliate is very similar to that of Halofolliculina corallasia from the Indo-Pacific, which is known to cause skeletal eroding band. None of the other 31 genera in the family Folliculinidae are known to cause diseases in corals or in any other animal species. The presence of this ciliate, which shows a prevalence comparable to that of other epizootics in the Caribbean, suggests it could be a new threat to the coral reefs of this region.
\end{abstract}

KEY WORDS: Coral $\cdot$ Ciliate $\cdot$ Disease $\cdot$ Caribbean $\cdot$ Coral reefs Resale or republication not permitted without written consent of the publisher

\section{INTRODUCTION}

Coral diseases have been reported world-wide, across oceans and bioregion provinces (Harvell et al. 1999). Nonetheless, most coral diseases show a narrow distribution and occur within specific geographic regions only. For instance, the yellow band syndrome, white plague type II and dark spots are restricted to the Caribbean (Weil 2004), while other syndromes such as pink spots, porites ulcerative white spot disease, bacterial bleaching, brown band (BrB) and skeletal eroding band (SEB) have only been reported for the Indo-Pacific (Willis et al. 2004) and the Red Sea (Winkler et al. 2004). Even the few syndromes that are common to different bioregions appear to have a different etiology. For example, molecular investigations showed differences in the bacterial consortium associated with black band disease (BBD) between bioregions (Frias-Lopez et al. 2003). Differences and similarities in the ecology and etiology of reef coral diseases among bioregions remain relatively unexplored, probably due to the fact that research started only 3 decades ago when Antonius (1973) was the first to describe a syndrome affecting corals.
Many parasitic and pathogenic species of protists are known for their ability to cause massive mortalities in marine invertebrates (Harvell et al. 1999, Gómez-Gutierrez et al. 2002). In comparison with other protozoan phyla, the phylum Ciliophora contains only a few parasitic species (described in Antonius \& Lipscomb 2001). Only 2 (SEB and BrB) out of the 18 coral syndromes which have so far been described (Sutherland et al. 2004), have been associated with the presence of the ciliates Halofolliculina corallasia (Antonius 1999, Willis et al. 2004) and Helicostoma nonatum (Borneman 2001), respectively. Both ciliates have been considered exclusive to the Indo-Pacific corals, although $H$. corallasia has been specifically searched for in the Caribbean (Antonius \& Lipscomb 2001). No other species of the genus Halofolliculina, and none of the other 31 genera in the family Folliculinidae, are known to cause diseases in corals or in any other animal. The distribution of $H$. corallasia within Indo-Pacific reefs remains elusive because qualitative surveys have been performed in the northern Great Barrier Reef (GBR), the Mauritius islands and the Sinai Peninsula only (Willis et al. 2004). In this study, we report for the first time a folliculinid ciliate of the genus Halofolliculina sp. associated with 10 hard coral species from the Caribbean. 


\section{MATERIALS AND METHODS}

In April 2004, we first observed a folliculinid ciliate on the hard coral Eusmilia fastigiata (see Veron 2000 for an authoritative work on coral species) in the coastal National Park of Morrocoy, Venezuela (Fig. 1A). This finding prompted us to survey a month later the reefs of Dos Mosquises Sur at the National Park of Los Roques, an oceanic archipelago located $160 \mathrm{~km}$ north of the Venezuelan mainland (Fig. 1B). In Los Roques 3 reef habitats were surveyed: a shallow barrier reef ( 2 to $3 \mathrm{~m}$ depth) and a shallow and a deep (8 to $12 \mathrm{~m}$ depth) fringing reef. The barrier reef is more exposed to waves than the fringing reef, and the two are $1 \mathrm{~km}$ apart (Fig. 1C). On the barrier reef 2 zones were clearly distinguished; one dominated by Acropora palmata and the other by Acropora cervicornis. In the former zone, colonies were examined along 5 belt transects of $25 \times 2 \mathrm{~m}$ each, by carefully checking with magnifying lenses to verify the presence or absence of ciliates. In the zone dominated by A. cervicornis, we evaluated 20 quadrats of $0.25 \mathrm{~m}^{2}$. The quadrats were spaced $5 \mathrm{~m}$ apart, which allowed for evaluation of at least 7 physically separate thickets of A. cervicornis. Within each quadrat we counted the number of branches (defined as uninterrupted living tissue), and checked them for ciliates. The number of branches per quadrat ranged from 5 to 27. Five quadrats had $<25 \%$ cover, 8 had 25 to $50 \%$ cover, and 7 had 50 to $75 \%$ cover of A. cervicornis.

In the shallow fringing reef we evaluated 3 belt transects following the procedure described above for the Acrapora palmata zone. In the deep fringing reef, we searched for ciliates in coral colonies intercepting each of the three $25 \mathrm{~m}$ long transects. The prevalence of the ciliate was estimated as the ratio of the number of affected patches or colonies to the total number of patches or colonies inspected within the observed unit. In addition, for each patch of $A$. cervicornis prevalence was estimated as the number of branches with ciliates divided by the total number of branches.

Live coral samples were taken to the laboratory where the ciliates were examined using a stereo and compound microscope. All coral samples with ciliates remained in Bouin's fixative for $48 \mathrm{~h}$, were washed with tap water and finally stored in $70 \%$ ethanol for further microscopic examination.

\section{RESULTS}

The general morphology of the Caribbean ciliate is very similar to that of Halofolliculina corallasia from the Indo-Pacific (Fig. 2A). Both H. corallasia and the Caribbean form are sessile in a lorica with the cell body attached at its pointed posterior end. The lorica is sac-like with a rounded posterior, and a cylindrical neck that angles up from the surface at about $45^{\circ}$, with a single sculpture line circumscribing it. The cell is elongate with 2 conspicuous peristomial wings (Fig. 2A) bearing feeding cilia. Upon cell division (asexual reproduction), vermiform, migratory larval stages are produced (Fig. 2B). Also, the sessile forms seemed able to abandon their lorica and actively seek suitable substrata (Fig. 2C). Zooxanthellae were distinguishable in large numbers inside the ciliates (Fig. 2C), suggesting that ciliates might ingest the zooxanthellae. However, further examination is required to determine whether they are able to establish a symbiosis with the algae, as other protozoans do (Lobban et al. 2002). We are preparing a detailed anatomical description of the Caribbean folliculinid Halofolliculina sp. to be published in a forthcoming article.

Halofolliculina sp. was obse rved on Eusmilia fastigiata (Meandrinidae) at Morrocoy, and on the following 9 hard coral species at Los Roques: Acropora palmata, A. cervicornis, A. prolifera (Acroporidae), Colpophyllia natans, Montastraea annularis, M. faveolata, M. franksi, Diploria labyrinthiformis (Faviidae), and Madracis mirabilis (Astrocoeniidae). Coral colonies affected by the ciliates had a dark band that separated healthy and dead or bleached tissue

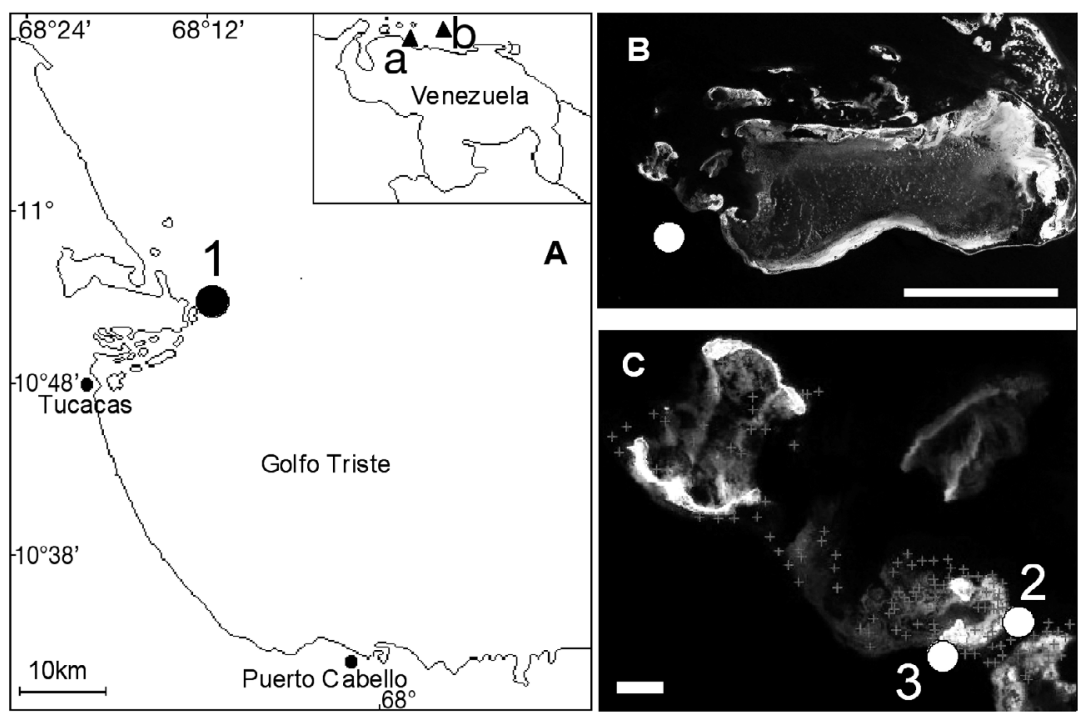

Fig. 1 (A) Cayo Sombrero (1) in the Morrocoy National Park (a on map inset); (B) Dos Mosquises Sur (O) in the Archipelago of Los Roques National Park (b on map inset), scale bar $=15 \mathrm{~km}$; (C) closer view of Dos Mosquises Sur showing the barrier reef (2) and the fringing reef (3), scale bar $=1 \mathrm{~km}$ 

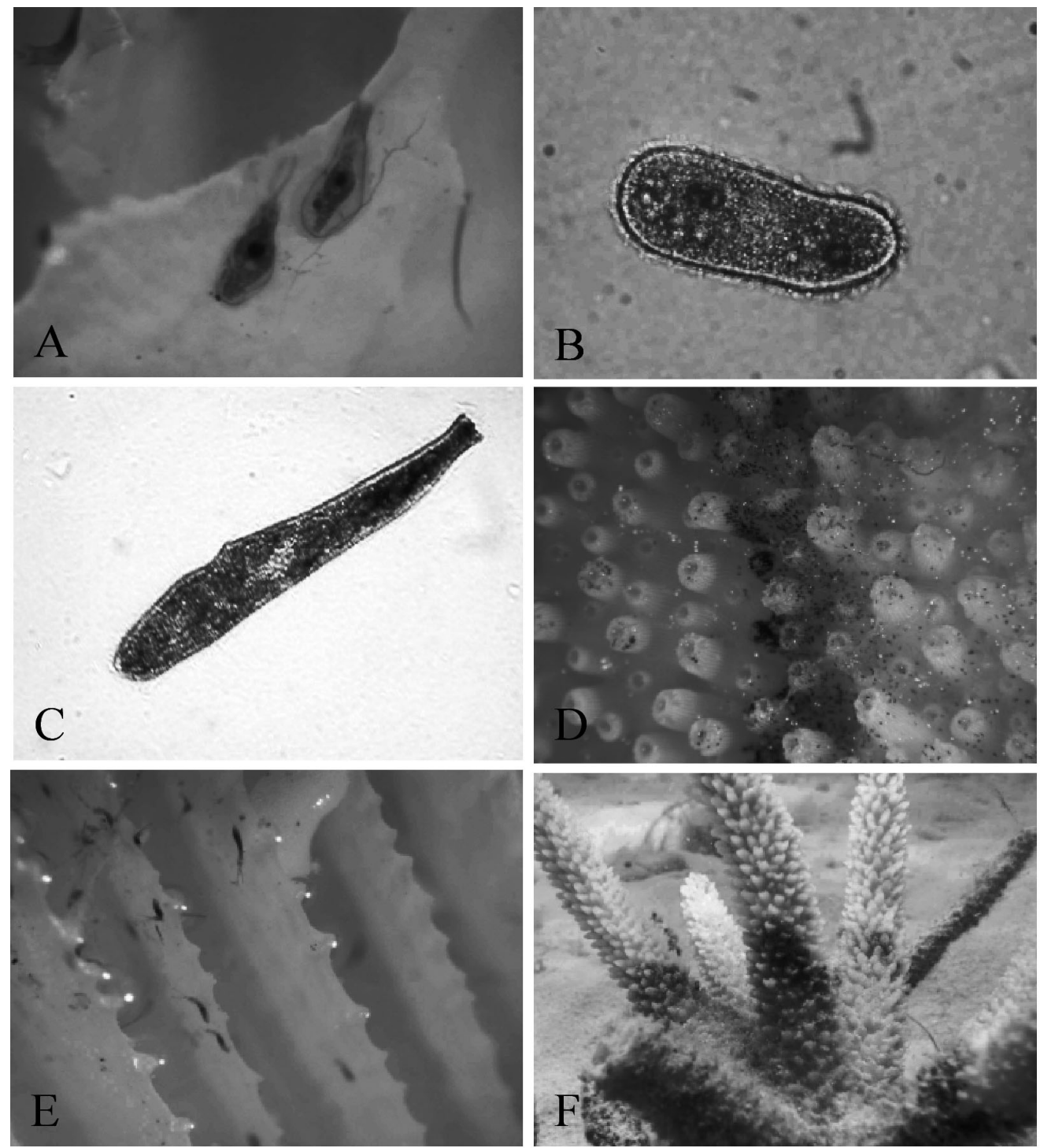

Fig. 2. Halofolliculina on Acropora palmata, Colpophyllia natans and A. cervicornis. (A) General aspect of the ciliate $(\times 50)$. (B) Young, free-swimming larval stage of the folliculinid (length $78 \mu \mathrm{m}$ ). (C) Presumptive adult, elongated, free-swimming stage outside of the lorica; zooxanthellae visible inside the protozoan $(\times 200)$. (D) Ciliates on A. palmata; live and dead tissue to the left and right of the band, respectively $(\times 12)$. (E) Ciliate in low density on $C$. natans $(\times 18)$. (F) A. cervicornis with ciliate clusters resembling black band disease

(Fig. 2D). Upon close examination in the field, the dark band consisted of small black dots (ciliates) that are easily discerned with magnifying lenses. At Los Roques, the most affected species, in terms of the density of the ciliates and their prevalence among colonies, were acroporids. In the barrier (waveexposed site), $85 \%$ of the patches of A. cervicornis had at least 1 branch affected by ciliates. For this coral species, the prevalence among branches within a patch ranged from 0 to $40 \%$ (up to 7 branches affected in a $0.25 \mathrm{~m}^{2}$ area), with a mean of $18 \%$ of the branches affected by the ciliate among all patches. In contrast, white band disease appeared in only 2 out of the 20 patches of A. cervicornis (10\%), and its prevalence per branch was $0.5 \%$. In addition, at this site, the ciliate had an overall prevalence of $1.2 \%$ among 1266 colonies belonging to 11 hard coral species. As only acroporids were affected here, the prevalence reached $11 \%$ in 101 colonies of A. palmata, whereas 2 out of 11 colonies of A. cervicornis and 2 out of 2 colonies of $A$. prolifera were also affected. Similarly, in the shallow fringing site, the ciliate had a prevalence of $2.6 \%$ among 513 colonies of 12 hard coral species. A. palmata was the only affected species here, and the prevalence of the ciliate was $10.5 \%$ among 133 colonies. Thus, at the 2 shallow sites, barrier and fringing 
reefs, A. palmata showed a similar prevalence of the ciliate.

In the deep fringing reef, which had a mean hard coral cover of $57 \%$, the prevalence of the ciliate was $9 \%$ among 91 colonies comprising 13 coral species. The ciliates were observed on 1 colony of Colpophyllia natans, 3 colonies of Montastraea annularis, and 4 colonies of $M$. faveolata. These coral species had a cover of 18,8 and $24 \%$, respectively. Ciliates were also observed outside sampling units in Madracis mirabilis and Diploria labyrynthiformis. We did not detect ciliates in any of the following species observed within the sampling units: Montastraea cavernosa, Meandrina meandrites, Isophyllastrea rigida, Diploria strigosa, Porites astreoides, P. branneri, P. porites, Siderastrea siderea, Agaricia agaricites and Favia fragum.

\section{DISCUSSION}

We provide the first report of a folliculinid ciliate associated with corals in the Caribbean. This ciliate was found in Venezuela on 10 hard coral species, including most major reef builders. In a reef at Los Roques, the prevalence of this ciliate was up to $85 \%$ among patches of Acropora cervicornis, $11 \%$ among A. palmata colonies, and from 3 to $9 \%$ for 20 hard coral species examined. The high prevalence among acroporids was similar between a wave-exposed reef site and a relatively less exposed shallow site. Ciliate densities appear to be fairly variable within and among coral species. While some colonies had very few ciliates (Fig. 2E), making it difficult to attribute tissue mortality to them, other colonies showed clusters of ciliates in high densities (Fig 2F). In colonies with high ciliate densities, it seems likely that ciliates infect coral tissues which have already been damaged by bleaching or predation, or affected by diseases such as white band disease. Further research is necessary to determine the set of conditions that affect ciliate density and the way this is associated with damage to corals.

Despite its abundance in Los Roques, this ciliate had previously remained unnoticed in the Caribbean, although many scientists have worked on diseases, and looked specifically for Halofolliculina corallasia (Sutherland et al. 2004). In particular, this ciliate was not found in reefs of at least 3 Caribbean countries surveyed between 1997 and 2000 (Antonius \& Lipscomb 2001). It is possible that this ciliate has remained unnoticed due to its superficial resemblance to BBD when it occurs in high densities (Fig. 2F). Also, the relatively low abundance of acroporids in most Caribbean reefs as well as their susceptibility to other diseases may have contributed to researchers overlooking this condition. Alternatively, it may represent a new threat to the corals in the region, as it is possible that the ciliate only recently invaded the Caribbean from the Indo-Pacific. This is a plausible hypothesis in view of the high rates of dispersion of marine parasites (McCallum et al. 2003) and the numerous damaging invasions that have occurred among marine ecosystems (Ruiz et al. 2000).

In conclusion, the high prevalence of this folliculinid and its capability to infect a large number of Caribbean coral species show that these ciliates are no longer restricted to the Indo-Pacific, but affect corals on a global basis.

Acknowledgements. We thank D. Bone for sharing his laboratory facilities, Fundación Científica Los Roques for allowing the use of their facilities, L. M. Márquez, G. Smith, P. Zanders, and $\mathrm{C}$. Bosque for their helpful comments on the manuscript, and 2 anonymous reviewers for additional comments.

\section{LITERATURE CITED}

Antonius A (1973) New observations on coral destruction in reefs. Assoc Isl Mar Lab Caribb 10:3

Antonius A (1999) Halofolliculina corallasia, a new coral-killer ciliate on Indo-Pacific reefs. Coral Reefs 18:300

Antonius A, Lipscomb D (2001) First Protozoan coral-killer identified in the Indo-Pacific. Atoll Res Bull 481:1-21

Borneman EH (2001) Aquarium corals: selection, husbandry, and natural history. THF Publishing, Neptune City, NJ

Frias-Lopez J, Bonheyo GT, Qushend J, Fouke BW (2003) Cyanobacteria associated with black band disease in Caribbean and Indo-Pacific reefs. Appl Environ Microbiol 69:2409-2413

Gómez-Gutierrez J, Paterson WT, De Robertis A, Brodeur RD (2002) Mass mortality of krill caused by parasitoid ciliates. Science 301:339

Harvell CD, Kim K, Burkholder JM, Colwell RR and 9 others (1999) Emerging marine diseases - climate links and anthropogenic factors. Science 285:1505-1510

Lobban CS, Schefter M, Simpson AGB, Pochon X, Pawloswki J, Foissner W (2002) Ciliate-Symbiodinium symbiosis spotted on reefs. Coral Reefs 21:332

McCallum H, Harvell CD, Dobson A (2003) Rates of spread of marine pathogens. Ecol Lett 6:1062-1067

Ruiz GM, Rawlings TK, Dobbs FC, Drake LA, Mullady T, Huq A, Colwell RR (2000) Global spread of microorganisms by ships. Nature 408:49-50

Sutherland K, Porter JW, Torres C (2004) Disease and immunity in zooxanthellate Caribbean corals. Mar Ecol Prog Ser 266:273-302

Veron JEN (2000) Corals of the World. Australian Institute of Marine Science and Cooperative Research Centre, Townsville

Weil E (2004) Coral reef diseases in the wider Caribbean. In: Rosenberg E, Loya Y (eds) Coral health and disease. Springer-Verlag, Berlin, p 35-67

Willis BL, Page CA, Dindsdale EA (2004) Coral disease in the Great Barrier Reef. In: Rosenberg E, Loya Y (eds) Coral health and disease. Springer-Verlag, Berlin, p 69-104

Winkler R, Antonius A, Renegar DA (2004) The skeleton eroding band disease on coral reefs of Aqaba, Red Sea. PSZN I: Mar Ecol 25(2):129-144 